\title{
Assorted Methods of Making of Pricing Decisions in an Enterprise
}

\author{
Henryk Wnorowski ${ }^{1}$ \\ ${ }^{1}$ Faculty of Economics and Management, University of Bialystok, Poland, \\ h.wnorowski@uwb.edu.pl
}

\begin{abstract}
Decisions concerning price development are best visible in view of their direct impact on the market activities of the company and the general level of profitability. In every activity, the success is measured by an excess of sales revenue over the costs of used resources. In an ideal case, a determined price provides the highest margin resulting from an analysis of the sales volume, takes into consideration the customer's evaluation of the product/service, and allows to react to competitive threats and to fend off the competition's attacks. There is no single universal way to develop prices for various enterprise types, regardless of the conditions of demand, the specific character of the sector they operate in, or the competitive situation, even if we assume that the enterprise has only one goal of activity. That's why, Author recommends three price determination methods. The ways of price determination presented in this article are just the first step on the way to reach the optimal prices. The prices determined in such way, as well as product or service prices already functioning in the market, are subject to modification depending on the assumed goals, taking into consideration the character of demand for a given commodity and the behaviour of the competition.

Keywords: price, pricing decision, pricing policy, marginal revenue, marginal cost, price elasticity of demand
\end{abstract}

\section{Introduction}

Price $^{1}$ is a value of a commodity, expressed in money. In the market economy, the prices of commodities and services are developed at the level at which the demand for a specific commodity or service is balanced with the supply thereof. This is a so-called equilibrium price - see Figure 1.

If any price turns out to be higher (the demand cannot absorb the entire supply) or lower (the demand is not entirely satisfied) than the equilibrium price, then the market mechanism will act towards bringing such a price to the level of equilibrium.

If, at an overly high price, sellers are unable to sell out the full quantity of the commodity intended to be sold, they will reduce the price until their 


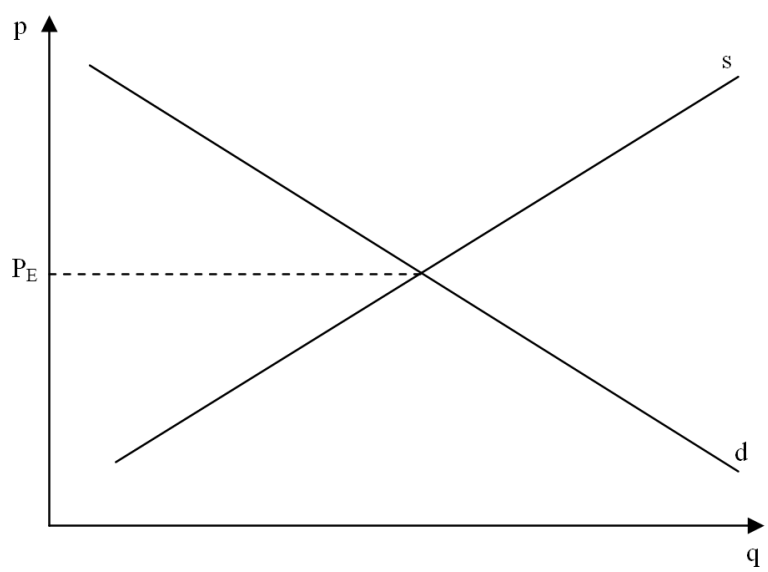

\section{Figure 1. Equilibrium price}

entire offer is absorbed by the demand. If, at a specific price, the demand fails to be satisfied entirely, then either the manufacturers increase the supply to such an extent that the market equilibrium is created at this price, or, if they are unable or do not want to do so, for one reason or another, to increase the supply, they take advantage of the competition between the purchasers who all would like to obtain a "deficit" commodity, and they increase the price to such an extent that the demand declines and equals the level of supply.

In a theoretical model of a perfect market, every commodity should have only one demand and supply equilibrium price in a specific market, i.e., in all points of sale of the same market, the price paid for the same commodity should be uniform and correspond with the marginal costs of manufacturing. As long as the market equilibrium price is higher than the marginal costs of manufacturing of the commodity, it will be profitable to the manufacturers to increase the production and supply. However, an increase in supply, with other conditions unchanged, causes a reduction of the equilibrium price. The increase in production and reduction of the market equilibrium price of the commodity takes place until the moment when the marginal cost of manufacture and the equilibrium price equal with each other, since this causes expiration of the impulse for further increase in production.

The mechanism described above only acts automatically in theory. In the practice of functioning of enterprises, determination of prices for own products or services is a subject of conscious (purposeful), multilaterally conditioned managerial decisions. ${ }^{2}$ Therefore, the goal of the present article is to present assorted methods of price determination in an enterprise. ${ }^{3}$ 


\section{The essence and significance of the price development process}

Of all decisions adopted by the management, those concerning price development are best visible in view of their direct impact on the market activities of the company and the general level of profitability. In every activity, the success is measured by an excess of sales revenue over the costs of used resources. In an ideal case, a determined price provides the highest margin resulting from an analysis of the sales volume, takes into consideration the customer's evaluation of the product/service, and allows to react to competitive threats and to fend off the attacks of the competition. ${ }^{4}$

A high product price discourages a large part of the market, while a low one encourages large groups of purchasers to buy more. This causes high prices to limit a potential market for products, and low ones to broaden this market. The quantity of any commodity which is manufactured and sold, as well as the price at which it is sold, are mainly determined by conditions on a given product market, through determination of a minimum of qualitative diversity between competitive brands.

Managers know very well that prices have a large influence on the profit. However, they seldom change prices in stable times, for several reasons. They often have neither expertise nor experience in pricing policy, so they are simply afraid of worsening the financial situation of their organization suddenly and, in addition, on their own initiative. One should admit that their fears are often substantiated (Zinoecker, Gorzeń, Kraus 2009, p. 15).

Nevertheless, in early 2013, more than nine out of ten Polish companies assessed that a struggle for lower prices was going on in their sector. More than a half of them (54\%) admitted they were involved themselves, albeit

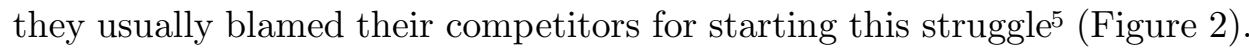

Proper determination of prices also has a macroeconomic significance, since the nationwide welfare arises when the assets are transferred from the low valued uses to the high valued uses. An individual determines the value of a commodity or a service as an amount he or she wants to pay for it. Such a tendency includes a desire to own a commodity and an ability to pay for it. We say that the value of a commodity is a maximum price to be accepted by the buyer. Similarly, the seller will not agree to a price lower than a minimal one which constitutes the lower limit and corresponds to the costs incurred by the seller.

The purchaser is willing to buy if the price decreases below his maximum price, and the seller sells for the same egoistic reason - because the price exceeds his minimum price. Both buyers and sellers benefit, otherwise they 


\section{Have you recently experienced a higer price pressure? \\ (answers in percentage)}

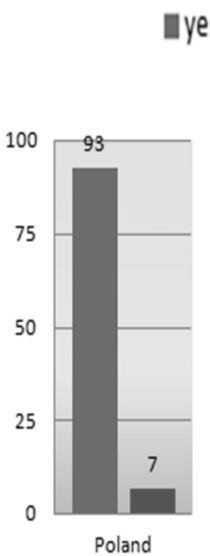

Ines no

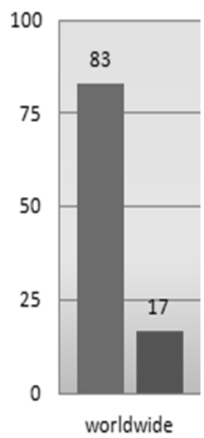

nCustomers expect increasingly more discounts

- Price competition / new competitors

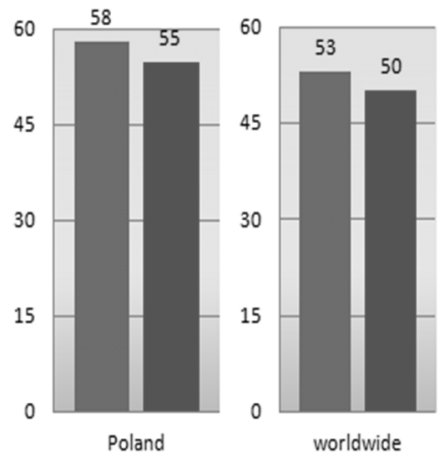

Figure 2. Price competition in Poland and worldwide (Polish companies are more susceptible to price pressure)

Source: Simon-Kucher \& Partners, after "Rzeczpospolita"

would not enter the transaction. These voluntary transactions are what creates the welfare.

\section{Pricing decisions in conditions of various enterprises}

There is no single universal way to develop prices for various enterprise types, regardless of the conditions of demand, the specific character of the sector they operate in, or the competitive situation, even if we assume that the enterprise has only one goal of activity. For our further argumentation, we assume that this goal is maximization of the profit.

With these assumptions, we can recommend, in particular, three price determination methods, namely:

\section{Pure sales problem:}

The enterprise is in a situation where it produces a commodity or a service, not incurring any variable costs in the progress (or these costs are so low they can be ignored in the analysis). Examples of such situations and enterprises include:

- software development companies, striving to determine an optimum sales price of their software, 
- mobile network operators, striving to enter as many contracts as possible,

- professional football clubs determining ticket prices for matches played at their own stadiums,

- airlines, railways or bus lines striving to fill the seats in their vehicles making scheduled trips,

- manufacturers striving to sell the stock of their products, the shelf life of which is coming to an end.

All these cases are similar in this respect that variable costs are basically nonexistent or nominal. The cost of an additional software copy can be easily neglected. In case of an airline or a sports event, the revenue depends exclusively on the number of sold tickets. Costs connected with an additional passenger or match spectator are inconsiderable if we have decided that a given flight or match will take place.

In each of these cases, an enterprise maximizes the profit, determining the price and production volume in a way which will guarantee revenue maximization. Since we already know that the sales volume is a reaction to the price level, let us formulate a question how an enterprise determines a price level allowing it to maximize the revenue.

There are two equivalent answers to this question:

1. The first one suggests the use of the universal principle: $M R=M C$

( $M R$ - marginal revenue; $M C$ - marginal cost)

In our case, the marginal cost is zero $(M C=0)$, thus the applied rule becomes $M R=0$.

The interpretation of this condition is as follows: if the $M R$ is positive, the enterprise should increase the production and sale, which will allow it to increase the revenue. If, on the other hand, the MR is negative, the enterprise should reduce the sale. In other words, the point ensuring revenue maximization is a sales volume at which $M R=0$.

2. The second equivalent answer (also resulting from the first one) states that the revenue reaches the maximum at the point in which the elasticity is equal to unity.

\section{Optimal pricing policy:}

This method is applied under conditions of a typical enterprise manufacturing typical products. ${ }^{6}$ One can say it is, in a sense, a fulfillment of a common wisdom that the price should depend on both the demand and the costs.

To this end, we introduce a concept of a covering surplus in an enterprise and express it as: $(P-M C) Q$, where: 
$P$ - price

$M C$ - marginal cost

$Q$ - production volume

When determining the price level of its products, an enterprise strives to maximize the amount of the covering surplus, and therefore the profit. This, in turn, depends on the price elasticity of the demand. A price increase means an increase in the unit surplus, $P-M C$. However, a higher price also causes, to a greater or lesser degree, a decline in the total sale volume $Q$. If the sales react relatively poorly to price changes (the demand is relatively inelastic), the enterprise can raise the price and increase the unit surplus at only a slight limitation of the sales volume. Such situation is an argument in favour of higher prices.

And if the demand is very elastic, then a price increase causes a significant decline in the sales volume, and therefore, a decline of the total covering surplus. This means that in such conditions, the best way to maximize the covering surplus (as well as the profit) is an action opposite to the previous one. In order to increase its profitability, the enterprise should apply the price reduction policy. We can express such common-sense dependence in the form of a simple formula the application of which allows the enterprise to determine a profit-maximizing price. A price which is optimal from the viewpoint of an enterprise is determined as follows:

$$
\frac{P-M C}{P}=-\frac{1}{E_{p}}
$$

This equation is called the principle of optimal markup over marginal costs and may be interpreted intuitively. It means that the level of the markup over the marginal cost, expressed as a percentage of the price, is inversely proportional to the price elasticity of the demand for a given commodity or service. This principle is intuitively convincing. The left side of the equation shows the actual surplus (margin) of the price over the marginal cost, $(P-$ $M C / P)$, while the right side illustrates the desired surplus (margin) which is the reciprocal of elasticity, $\left(1 / E_{p}\right)$. If the actual surplus is higher than the desired one, we reduce the price, because the $M R$ is higher than the $M C$, and vice versa (Froeb, McCann, 2012, pp. 93-94). Since, as a matter of fact, we are concerned with price determination, it is convenient to transform the equation to the following form:

$$
p=\left(\frac{E_{p}}{1+E_{p}}\right) M C,
$$

which determines the price directly. 
3. Price determination on the basis of total costs:

In this case, the structure of the price is as follows:

$$
P=(1+m) A C
$$

where:

$A C$ - average total cost

$m$ - markup over the price exceeding the average cost (margin)

When developing prices on the basis of costs, the point of departure for the final price is assumed to be the costs of manufacturing a product or the cost of purchase in case of trade companies. This may be material costs, salary costs, transport costs etc. Subsequently, the markup is added, and the sum of costs and the markup constitute the price. An objection towards this method is that it does not take into consideration the market conditions, only the conditions in a given enterprise.

And, as a matter of fact, this is true, yet nevertheless this method has a value. Not in the aspect of price determination but in the aspect of checking whether the price that is to be determined will be profitable. Here, internal costs of the company may play the role of a foundation - a basis for price development (Lunden 2009, p. 20).

\section{Conclusion}

Prices are the basis of a real success of an enterprise. Effective price management is not only a theory. ${ }^{7}$ The ways of price determination presented in the present article are just the first step on the way to reach the optimal prices. The prices determined in such way, as well as product or service prices already functioning in the market, are subject to modification depending on the assumed goals, taking into consideration the character of demand for a given commodity and the behaviour of the competition.

The basic premise we cannot forget about in the process of price modification is the understanding of the dependence between the sales volume determined by the price and the profitability of an enterprise. ${ }^{8}$

For each level of price modification, there is a corresponding (opposite) change of sales volume, which would allow to maintain the margin amount on a constant level. This dependence is determined by an additional sales volume, necessary in order to maintain the current level of the total margin (in case of price reductions), or an acceptable decline in the volume, at which the total margin will remain on an unchanged level (in case of price increases). One should keep in mind that this relation is not identical in both situations. 


\section{N O T E S}

1 The classic microeconomy focuses on the price. When workforce is cheap and interest rates are high, average investors and managers prefer activity based on human effort. In an opposite situation, they focus on capital-consuming production technologies. Subsequently, guided by the price, they decide in what amount to produce a given commodity. (Mellor, Coulton, Chick, Bifulco, Mellor and Fisher, 2011, pp. 17-18).

${ }^{2}$ Various aspects of the internal and external environment of the enterprise, as well as the possibility of marketing usage of the price, impact the decisions on the final price level. An example can be the fact that every enterprise functions under conditions of a more or less dynamic competition. Even monopolists, manufacturing products which cannot be produced by any other company, should reckon with the fact that almost every product has its substitutes. Therefore, if the monopoly's commodity is offered, in the buyers' opinion, at an overly high price, they will transfer their demands to substitutes, causing the monopoly to decrease its sales and profits. Therefore, every enterprise must carefully monitor prices, as well as prices of substitutes, in order to prevent a significant price range to its disadvantage and a weakening of its position on the market.

3 The author's intent is to show only the initial stage of managerial pricing decisions in an enterprise. We will not find an answer here to the question what price should be included in the official price list of the company and how it will be finally modified through treating the price as an instrument of a marketing mix.

${ }^{4}$ Correct determination of prices is the quickest and most effective way for a company to achieve a maximum profit. A correct price can increase the profit quicker than an increase in the sales volume, while a wrongly determined price can decrease it equally fast (Hanna, Dodge, 1997, p. 15). Correct determination of a price and a conducted pricing policy can attract new customers as well as allow the company to achieve the planned sales and a favourable financial result. Pricing always remains a market game between the competitively low price level and a profit-maximizing price. The range of a price optimizing the company's profitability is limited by the barrier of costs from below and the barrier of demand from above. A price can be an effective instrument of competition if it takes into account the situation of the destination market, complementary and compensatory relations to the product and other elements of the marketing programme (Sobczyk 2010, p. 182).

5 Results of research by the consulting company Simon-Kucher \& Partners, which included 23 countries of the world (see Rzeczpospolita, 5 February 2013).

6 The use of this method is only substantiated in determination of prices for goods and services with an elastic demand. If the demand is inelastic, no price will enable the enterprise to achieve the maximum profit.

7 There are companies which mainly owe their position to this very competency. Let us take the Porsche concern. Its head, Dr. Wendelin Wiedeking, claims that "professional price management is one of the foundations of our business model and one of the main causes of the recent success of our company". And the success of this niche car manufacturer is unquestionable. According to the German B\&D-Forecast Institute, in 2006, the company earned on average almost 22 thousand Euros gross from each sold Porsche more than any other brand, including nine times more than the Munich's BMW. Another well-known company which gains advantage over the competitors thanks to effective price management is Nestle food concern. This company was able to effectively transfer the increase in food costs to its consumers. In the first quarter of 2008, it gained a growth rate at the level of $9,8 \%$. More than a half of this growth $(5,3 \%)$ resulted from properly introduced price increases, and the other $4,5 \%$ - from the increase in sales quantity. These values significantly exceed the average of the sector, and they show that the way an enterprise manages the prices has a significant impact on its financial results (Zinoecker, Gorzeń, Kraus 2009, p. 108). 
8 It would seem that it is an almost obvious issue, yet many companies still seem to forget about it and adopt decisions on price transformations while being not fully aware of the relation between quantity and profitability.

\section{R E F E R E N C E S}

Firmy pod presja cenowa klientów i konkurentów, "Rzeczpospolita" 5.02.2013.

Froeb, L. M., McCann B.T. (2012). Ekonomia menedżerska. Warszawa: PWE.

Hanna, N., Dodge, M.R. (1997). Kształtowanie cen. Strategie i procedury. Warszawa: PWE.

Lunden, B. (2009). Kształtowanie cen. Praktyczny poradnik. Gdańsk: Wydawnictwo BL Info Polska.

Mellor, R.B., Coulton G., Chick, A., Bifulco, A., Mellor, N., Fisher A. (2011). Przedsiębiorczość. Warszawa: PWE.

Sobczyk, G. (2010). Polityka cen. In: G. Sobczyk (ed.). Zarządzanie sprzedażą w przedsiębiorstwie handlowym i usługowym. Warszawa: PWE.

Zinoecker, R., Gorzeń W., Kraus M. (2009). Wykorzystaj trudne czasy do optymalizacji cen. Harvard Business Review Polska. July-August. 